\title{
Effects of underfeeding on body reserves variations and on energy efficiency of lactating Charolais cows
}

\author{
J Agabriel 1, M Petit 1, A Ollier 2, Y Chilliard 2 \\ IINRA, Laboratoire Adaptation des Herbivores aux Milieux, ; 2INRA, Laboratoire Sous Nutrition \\ des Ruminants, Theix, 63122 St-Genès-Champanelle, France
}

During winter beef cows mobilize their body reserves which are mainly composed of lipids (1984, Wright and Russel, Anim Prod, 38, 23-32). In French beef breeds, in usual management systems, lipids may account for $7 \%$ of the body mass in the thinnest cows, (scored 1.0 on 5 ) and $22 \%$ of the body mass in the fattest (scored 4.5 on 5).

In addition, adaptation of energy metabolism to undernutrition can reduce maintenance requirement of the lactating cow by 13 to $20 \%$ (Ortigues, 1991, Repr Nutr Dev, 31, 593-616). The objective of the present experiment was to measure the quantity and the composition of body reserves mobilized by lactating Charolais cows fed either a high $(\mathrm{H})$ or a low $(\mathrm{L})$ level of food supply, then to estimate their energy maintenance requirements by calculating energy balance.

Nine multiparous cows aged 4 to 9 years, in good initial body condition (rated 3.0 over 5 ), and fed individually in tying stalls, were allocated randomly to the high $(n=4)$ or the low $(n=5)$ energy level, for a 16 week experimental period, 2 weeks after calving. Diets consisted of $85 \%$ hay (first cut and second cut) and $15 \%$ concentrate (barley and soybean meal). Rations were individually adjusted to requirements (INRA 1988) plus 1 LFU for $\mathrm{H}$ cows or minus 2.5 LFU for $\mathrm{L}$ cows. Digestibility of diets were obtained on each cow by total faecal collection during 10 days.

All the cows were fitted with rumen canulae, which made it possible to remove their rumen contents in order to estimate their body mass (live weight - rumen content/0.75). Body composition was estimated from diameter of subcutaneous adipocytes (ACD : Robelin, 1982, Anim Prod, 34, 347-350) at the beginning and the end of the experimental period. Body condition score (BCS) was rated by palpation (Agabriel et al, 1986, Bull Tech CRZV Theix INRA, 66, 43-50).

On average $H$ and $L$ cows weighted initially 630 $\mathrm{kg}$ and their body mass $(515 \mathrm{~kg})$ included $79 \mathrm{~kg}$ lipids $(15.3 \%)$. During experimental period, rumen content of $\mathrm{H}$ cows increased from 88 to $99 \mathrm{~kg}(10.4$ to $11.4 \%$ dry matter DM) while remaining near $85 \mathrm{~kg}$ in L cows with a significative decrease of DM content (12 to $9.4 \% \mathrm{P}<0.01)$. $L$ cows lost $62 \mathrm{~kg}$ of body mass $(\mathrm{P}<0.01), 1.5$ point of $\mathrm{BCS}(\mathrm{P}<0.01)$ and $53 \mathrm{~kg}$ of lipids $(\mathrm{P}<0.01)$. Corresponding values for $\mathrm{H}$ cows were $18 \mathrm{~kg}$ (NS), 0.1 point and $18 \mathrm{~kg}$. So lipids accounted respectively for 85 and $100 \%$ of the loss of body mass. At the end of the experiment, lipid content of the body mass of $L$ cows was estimated to $5.5 \%$.

The cows produced on average $7.2(\mathrm{H})$ and 5.3 (L) $\mathrm{kg}$ of milk/day $(P<0.05)$, milk fat content was estimated three times after hand milking half a udder while the calf sucked the other half : $44 \mathrm{~g} / \mathrm{kg}(\mathrm{H})$ and $40 \mathrm{~g} / \mathrm{kg}(\mathrm{L})$ of tat per $\mathrm{kg}$ of milk $(\mathrm{P}<0.05)$.

Maintenance requirements were defined as the difference between the net energy supplies by the food (computed from the digestibility of organic matter measured in each cow) and by the body mass loss (with a $85 \%$ efficiency), and the net energy used for milk secretion. They were 7.3 and $5.9 \mathrm{LFU} /$ day for $\mathrm{H}$ and $\mathrm{L}$ cows equivalent to $24 \%$ less in the latter group. This can represent the increase of efficiency induced by adaptation to undernutrition.

\begin{tabular}{|c|c|c|c|c|c|c|}
\hline & $\begin{array}{l}\text { Initial LW } \\
(\mathrm{kg})\end{array}$ & $\begin{array}{l}\text { Initial EBW } \\
(\mathrm{kg})\end{array}$ & Initial $A C D(\mu)$ & $\begin{array}{c}\text { EBW } \\
\text { Change }(\mathrm{kg})\end{array}$ & $\begin{array}{c}\text { BCS } \\
\text { Change }\end{array}$ & $\begin{array}{c}\text { ACD Change } \\
(\%)\end{array}$ \\
\hline Low & 631 & 517 & 66 & -62 & -1.5 & -38 \\
\hline \multirow[t]{2}{*}{ High } & 629 & 513 & 73 & -18 & -0.1 & -15 \\
\hline & Milk (kg/d) & $\begin{array}{c}\text { OM } \\
\text { digestib. \% }\end{array}$ & $\begin{array}{l}\text { NE L supplies } \\
\text { LFU/d (1) }\end{array}$ & $\begin{array}{l}\text { NE L from } \\
\text { tissues LFU/d (2) }\end{array}$ & $\begin{array}{l}\text { NE for milk } \\
\text { LFU/d (3) }\end{array}$ & $1+2-3$ \\
\hline Low & 5.3 & 69.6 & 5.6 & 2.5 & 2.2 & 5.9 \\
\hline High & 7.2 & 69.0 & 9.9 & 0.7 & 3.3 & 7.3 \\
\hline
\end{tabular}

